This PDF is a selection from a published volume from the National Bureau of Economic Research

Volume Title: The Design and Implementation of U.S. Climate Policy

Volume Author/Editor: Don Fullerton and Catherine Wolfram, editors

Volume Publisher: University of Chicago Press

Volume ISBN: 0-226-36914-0; 978-0-226-26914-6

Volume URL: http://www.nber.org/books/full10-1

Conference Date: May 13-14, 2010

Publication Date: September 2012

Chapter Title: Spillovers from Climate Policy to Other Pollutants

Chapter Author(s): Stephen P. Holland

Chapter URL: http://www.nber.org/chapters/c12148

Chapter pages in book: (p. 79 - 90) 


\title{
Spillovers from Climate Policy to Other Pollutants
}

\author{
Stephen P. Holland
}

\subsection{Introduction}

Spillovers from climate policy (also known as ancillary benefits or ancillary costs) have important implications for policy design, modeling, and benefit-cost analysis. Spillovers arise since climate policy could lead, for example, to a reduction in particulate matter (PM) emissions as well as $\mathrm{CO}_{2}$ emissions. In this case, the ancillary benefits of reduced PM emissions from the policy should be included in a benefit-cost analysis and may well lead the benefit-cost analysis to recommend more stringent climate policies. Unfortunately, spillovers can be either positive or negative since firms change production processes in response to climate policies, and these changes may lead either to an increase or decrease in emissions of other pollutants. After presenting a theoretical description of spillovers from climate policy, this chapter empirically tests for and decomposes climate policy spillovers in electric power generation.

Climate policy spillovers have received attention in the estimation of health benefits from reduced air pollution. This extensive literature, which is recently surveyed in Bell et al. (2008), varies considerably in its sophistication with regard to air quality modeling and the responses of polluters to climate

Stephen P. Holland is associate professor of economics at the University of North Carolina at Greensboro and a research associate of the National Bureau of Economic Research.

Special thanks to Severin Borenstein, James Bushnell, Chris Ruhm, and Catherine Wolfram for helpful discussions. Thanks to the University of California Energy Institute (UCEI) for generous research support during this project. Thanks also to seminar participants at the University of North Carolina at Greensboro and at UCEI and to Michael Mills for valuable research assistance. For acknowledgments, sources of research support, and disclosure of the author's material financial relationships, if any, please see http://www.nber.org/chapters/c12148.ack. 
policy. ${ }^{1}$ For example, Cifuentes et al. (2001) simply assumes climate policy uniformly reduces pollution across all spatial areas. Other studies use much more sophisticated air quality modeling to estimate the effects of emissions reductions. Bell and colleagues conclude that although the various studies are difficult to compare, the results provide "strong evidence" that the shortterm ancillary benefits to public health of climate policy are "substantial."

Burtraw et al. (2003) focus on the responses to climate policy of electric power generators. ${ }^{2}$ Using a sophisticated simulation model of electricity supply, the authors show that a carbon tax would have ancillary health benefits from reduced $\mathrm{NO}_{x}$ emissions of about eight dollars per metric ton of carbon. Since emissions of $\mathrm{SO}_{2}$ are capped, they note that there are no ancillary health benefits from $\mathrm{SO}_{2}$ emissions, but they estimate additional benefits from avoided future investment in emissions control equipment. Groosman, Muller, and O’Neill (2009) estimate similar effects with a sophisticated model of pollutant transport. ${ }^{3}$

Ancillary benefits from climate policy have also been studied in agriculture and forestry where climate policy could benefit soil quality, wildlife habitat, water quality, and landscape aesthetics. ${ }^{4}$ Finally, ancillary benefits have been estimated to be substantial in developing countries where regulation of pollutants may be less stringent. ${ }^{5}$

\subsection{The Theory of Spillovers from Climate Policy}

Emissions are generally modeled using one of three equivalent approaches: as an input in the production process, as a joint product that is a "bad," or as abatement from some hypothetical level, for example, business as usual. The first approach has a number of advantages for modeling spillovers from climate policy since it is readily adaptable to modeling multiple pollutants and allows for a broad range of substitution possibilities. Moreover, it allows a simple way to model climate policies, for example, a carbon tax or cap and trade, as an increase in the price of $\mathrm{CO}_{2}$ emissions (from a zero price).

In this framework, climate policy spillovers are shifts in input demands in response to an increase in the price of $\mathrm{CO}_{2}$. Theory shows that input

1. See also European Environment Agency (2004).

2. Ancillary benefits have also been studied in transportation; see Walsh (2008) and Mazzi and Dowlatabadi (2007).

3. The more conservative estimates in Groosman and colleagues recognize that emissions of $\mathrm{SO}_{2}$ are capped.

4. See Feng, Kling, and Gassman (2004), Plantinga and Wu (2003), and Pattanayak et al. (2002). Elbakidze and McCarl (2004) point out that ancillary benefits must be skeptically considered with agricultural offsets since offset emissions reductions from other sectors might also have ancillary benefits.

5. See Dudek, Golub, and Strukova (2003) for analysis of ancillary benefits in Russia; Dessus and O'Connor (2003) for analysis of Chile; and Joh et al. (2003) for analysis of Korea. Greenstone (2003) studies pollutant spillovers across media and finds little evidence that the CAAAs increase releases into waterways and the ground. 
demand may either increase or decrease, depending on whether the input is a substitute or a complement to $\mathrm{CO}_{2}$. Additionally, the effects of climate policy can be decomposed into two effects: an output effect, which generally decreases the demand for all inputs, and a substitution effect, which depends on whether the inputs are net substitutes or net complements for $\mathrm{CO}_{2}{ }^{6}$ Importantly, demand for pollution inputs that are net substitutes can still fall with climate policy if the output effect outweighs the substitution effect. ${ }^{7}$

To illustrate these principles, consider electricity generation that leads to emissions of $\mathrm{SO}_{2}$ and $\mathrm{NO}_{x}$, as well as $\mathrm{CO}_{2}$. Suppose climate policy caused dual fuel generating units to switch from fuel oil to natural gas. Since natural gas generally has lower sulphur content than fuel oil, $\mathrm{SO}_{2}$ and $\mathrm{CO}_{2}$ would be net complements: for a given amount of electricity emissions of $\mathrm{SO}_{2}$ would be lower in response to climate policy. Since the output effect also serves to reduce $\mathrm{SO}_{2}$ emissions, climate policy would have ancillary benefits from $\mathrm{SO}_{2}$. Now suppose that climate policy caused natural gas-fired generating units to increase their combustion temperature, which reduces $\mathrm{CO}_{2}$ emissions but increases $\mathrm{NO}_{x}$ emissions. In this case $\mathrm{CO}_{2}$ and $\mathrm{NO}_{x}$ would be net substitutes. Note however, that since the output effect leads to a reduction in $\mathrm{NO}_{\mathrm{x}}$ emissions, the overall effect may still be a reduction in $\mathrm{NO}_{\mathrm{x}}$ emissions from climate policy if the output effect is stronger than the substitution effect. Thus, climate policy could have ancillary benefits or ancillary costs.

Spillovers are illustrated in figure 5.1 for the case of electricity production with emissions of $\mathrm{CO}_{2}$ and $\mathrm{NO}_{x}$. The first panel of figure 5.1 shows the input demand for $\mathrm{CO}_{2}$. If marginal productivity is decreasing (the usual case) then the input demand (equivalently the value of the marginal product) is downward sloping. The firm would increase use of an input if the value of the marginal product were greater than the input cost. Thus at the optimum, the value of the marginal product equals the input cost. In the unregulated equilibrium, this marginal product would be zero and $\mathrm{CO}_{2}$ emissions would be $e_{\mathrm{CO}_{2}}^{0}$. If climate policy increases the price of $\mathrm{CO}_{2}$ emissions to $t_{\mathrm{CO}}$, for example through a carbon cap or tax, then $\mathrm{CO}_{2}$ emissions would fall to $e_{\mathrm{CO}_{2}}^{1}$.

Panel B of figure 5.1 illustrates the spillovers to $\mathrm{NO}_{\mathrm{x}}$ emissions from climate policy. In the absence of climate policy, the $\mathrm{NO}_{\mathrm{x}}$ input demand is illustrated by the downward sloping solid line and $\mathrm{NO}_{\mathrm{x}}$ emissions are $e_{N O_{r}}^{0}$. The response of $\mathrm{NO}_{\mathrm{x}}$ emissions to climate policy depends on two factors: (a) whether $\mathrm{NO}_{x}$ and $\mathrm{CO}_{2}$ are substitutes or complements, and (b) regulations on $\mathrm{NO}_{x}$ emissions. In general $\mathrm{NO}_{x}$ and $\mathrm{CO}_{2}$ can be substitutes or

6. These effects are equivalent to income and substitution effects from demand theory. Deschênes (chapter 2, this volume) develops an equivalent framework for labor demand with scale and substitution effects.

7. Decomposing responses into output and substitution effects is also useful since output effects may not be effective for reducing emissions if regulations are incomplete or firms have market power. See Holland (2012) for further discussion of output effects with incomplete regulation. 


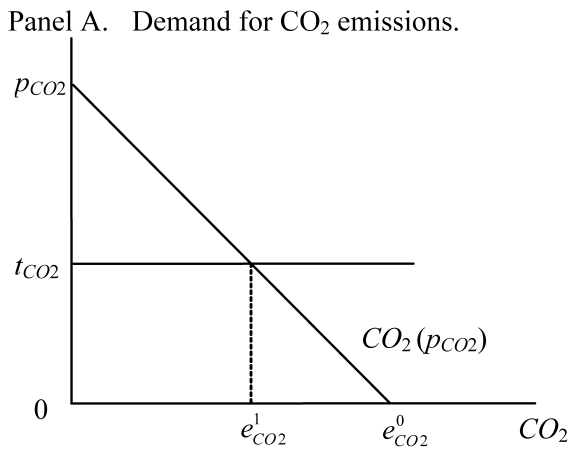

Panel B. Demand for $\mathrm{NO}_{\mathrm{x}}$ emissions.
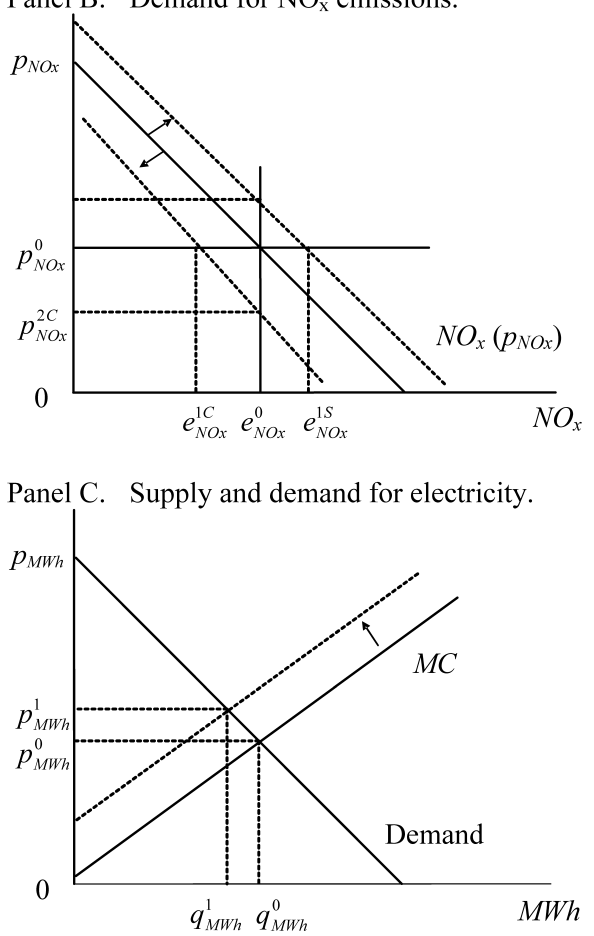

Fig. 5.1 Graphical model of spillovers from climate policy

complements. If $\mathrm{NO}_{x}$ and $\mathrm{CO}_{2}$ are complements, then climate policy leads to an inward shift in the input demand for $\mathrm{NO}_{x}$, that is, decreases the demand for $\mathrm{NO}_{\mathrm{x}}$ emissions. On the other hand, if $\mathrm{NO}_{\mathrm{x}}$ and $\mathrm{CO}_{2}$ are substitutes, then climate policy increases the demand for $\mathrm{NO}_{\mathrm{x}}$ emissions.

Whether or not climate policy changes, $\mathrm{NO}_{\mathrm{x}}$ emissions depends crucially on the environmental regulation of the $\mathrm{NO}_{\mathrm{x}}$ emissions. Two polar 
cases illustrate the effects: cap and trade in $\mathrm{NO}_{\mathrm{x}}$ versus a $\mathrm{NO}_{\mathrm{x}}$ tax. If $\mathrm{NO}_{x}$ is subject to an emissions cap (as in RECLAIM or in the $\mathrm{NO}_{\mathrm{x}}$ Budget Program), then climate policy does not change $\mathrm{NO}_{\mathrm{x}}$ emissions but changes the price of permits in the $\mathrm{NO}_{x}$ market. For example, if $\mathrm{NO}_{x}$ and $\mathrm{CO}_{2}$ are complements, then climate policy decreases demand for $\mathrm{NO}_{\mathrm{x}}$ emissions. Since emissions are capped, $\mathrm{NO}_{\mathrm{x}}$ emissions remain at $e_{N O_{\mathrm{x}}}^{0}$ and there are no spillover benefits, but the $\mathrm{NO}_{\mathrm{x}}$ price falls from $p_{N O_{x}}^{0}$ to $p_{N O_{x}{ }^{2}{ }^{2}}$

On the other hand, if $\mathrm{NO}_{\mathrm{x}}$ emissions are subject to price regulation, then $\mathrm{NO}_{\mathrm{x}}$ emissions change in response to climate policy. For example, if $\mathrm{NO}_{\mathrm{x}}$ and $\mathrm{CO}_{2}$ are complements, then climate policy would decrease demand for $\mathrm{NO}_{x}$ emissions and emissions would decrease from $e_{N O_{x}}^{0}$ to $e_{N O_{x}}^{1 C}$. Alternatively, if $\mathrm{NO}_{\mathrm{x}}$ and $\mathrm{CO}_{2}$ are substitutes, then climate policy would increase $\mathrm{NO}_{\mathrm{x}}$ emissions from $e_{N O_{x}}^{0}$ to $e_{N O_{x}}^{1 S}$.

Panel C of figure 5.1 shows the effect of climate policy in the electricity market. Since climate policy increases the marginal cost of electricity production, the equilibrium price of electricity will rise from $p_{M W h}^{0}$ to $p_{M W h}^{1}$ and the equilibrium production will fall from $q_{M W h}^{0}$ to $q_{M W h}^{1}$. This output effect will serve to reduce emissions of both $\mathrm{CO}_{2}$ and $\mathrm{NO}_{\mathrm{x}}$. Note that the output effect makes it unlikely that $\mathrm{NO}_{x}$ and $\mathrm{CO}_{2}$ would be gross substitutes since the substitution effect (which increases $\mathrm{NO}_{\mathrm{x}}$ emissions) would need to outweigh the output effect (which decreases $\mathrm{NO}_{\mathrm{x}}$ emissions).

Holland (2010) illustrates the proper valuation of climate policy spillovers for benefit-cost analysis. Two results are noteworthy. First, spillovers can affect the optimal carbon price. In particular, if there are ancillary benefits, then the optimal carbon price would be set higher than the marginal damages. Second, spillovers should be included in benefit-cost analysis just as other benefits or costs are included. In fact, from a theoretical standpoint, spillovers are indistinguishable from changes in any other input, such as labor. However, care must be taken to evaluate environmental spillovers according to their damages since market prices are not available.

Holland (2010) also extends the theoretical analysis in this section by deriving theoretical predictions. In particular, both the input demand and conditional input demand must be decreasing in the own price and output effects must be negative. These predictions will aid in the identification of empirical models.

\subsection{Estimation Strategy}

Spillovers resulting from responses to climate policy cannot be directly estimated in industries that are not yet subject to climate policy. Moreover, in industries currently subject to climate policy, it would be difficult to dis-

8. Burtraw et al. (2003) note that the falling $\mathrm{NO}_{\mathrm{x}}$ price may have benefits from avoided future control equipment. 
entangle the effects of climate policy from the effects of other environmental regulations.

To overcome these difficulties, I exploit the symmetry of input substitution and estimate the response of $\mathrm{CO}_{2}$ emissions to the change in the price of $\mathrm{NO}_{\mathrm{x}}$ emissions. ${ }^{9}$ This has two advantages. First, $\mathrm{NO}_{\mathrm{x}}$ emissions have been regulated extensively so it is possible to design an estimation strategy with variation in $\mathrm{NO}_{x}$ regulations. Second, $\mathrm{CO}_{2}$ was not regulated, so there is no need to disentangle the effects of the $\mathrm{NO}_{\mathrm{x}}$ regulation from $\mathrm{CO}_{2}$ regulation. To proxy for changes in $\mathrm{NO}_{x}$ prices, I use changes in attainment status under the Clean Air Act Amendments (CAAAs). Regions that fail to achieve an ambient air quality standard are deemed to be in nonattainment. Designation as nonattainment under the CAAAs triggers additional regulations, which vary according to each state's implementation plan (SIP)..$^{10}$ In this study, attainment status for one-hour ozone proxies for the price of $\mathrm{NO}_{x}$, which is a primary ozone precursor. Since California had multiple changes into and out of attainment, the analysis focuses on California power plants.

The estimation strategy uses a fixed effects estimator. The basic estimating equation is:

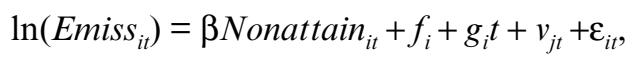

where Emiss $s_{i t}$ is emissions (of $\mathrm{NO}_{x}, \mathrm{CO}_{2}$, or $\mathrm{SO}_{2}$ ) from generating unit $i$ at time $t$; Nonattain $_{i t}$ is a dummy variable indicating that unit $i$ is in nonattainment for one-hour ozone at time $t ; f_{i}$ is a unit-specific fixed effect; $g_{i} t$ is a unit-specific linear trend; $v_{j t}$ is a market-year-month fixed effect for market $j$; and $\varepsilon_{i t}$ is the error term. To correct for possible serial correlation, the error term, $\varepsilon_{i t}$, is clustered at the generating unit.

The parameter of interest, $\beta$, indicates the response of emissions to a change in attainment status. Since the nonattainment dummy is a proxy for an increase in the price of $\mathrm{NO}_{x}$ emissions, the estimated coefficient captures the own price effect when $\mathrm{NO}_{\mathrm{x}}$ emissions is the dependent variable. With $\mathrm{CO}_{2}$ emissions as the dependent variable, the estimated coefficient captures the spillover. A positive (negative) coefficient indicates that $\mathrm{NO}_{x}$ and $\mathrm{CO}_{2}$ are gross substitutes (complements). The own and spillover conditional (net) effects can be estimated by controlling for output in equation (1), and the output effect can be estimated directly when output is the dependent variable. $^{11}$

9. Exploiting symmetry requires care since it only holds for marginal changes. See Holland (2010) appendix 2 for details on the symmetry of input substitution.

10. For detailed descriptions of the regulatory effects of nonattainment designation under the CAAAs, see Greenstone (2002).

11. By estimating $\ln \left(\right.$ Emiss $\left._{i t}\right)=\beta^{c}$ Nonattain $_{i t}+\beta^{M W h} \ln \left(M W h_{i t}\right)+f_{i}+g_{i} t+v_{j t}+\varepsilon_{i t}$ and $\ln \left(M W h_{i t}\right)=\beta^{\prime}$ Nonattain $_{i t}+f_{i}+g_{i} t+v_{j t}+\varepsilon_{i t}$ in addition to equation (1), all four derivatives in the Slutsky equation in Holland (2010) appendix 2 are estimated separately. However, the identity $\beta=\beta^{M W h} \beta^{\prime}+\beta^{c}$ holds since the sample and all conditioning variables are identical. 
Most of the potentially confounding variation is controlled for by the fixed effects. The unit-specific fixed effects capture any differences in emissions across units due to fuel-mix, generation technology, generator capacity, installed emissions control equipment, or any other time-invariant characteristics of the generating units. The unit-specific linear trends capture any trends at the unit level, for example, phasing out of old units. The marketyear-month fixed effects are a vector of indicators for each month of each year for each market; for example, one indicator is for January 1999 for the northern California market (NP15) and another indicator is for January 1999 for the southern market. The market-year-month fixed effects capture all variation over time such as seasonal effects and changes in relative fuel prices, in labor costs, in capital costs, and in regulations affecting all generators as well as differences across the markets. This flexible set of fixed effects captures most of the potentially confounding effects.

Given this extensive set of nonparametric controls, model identification is based on variation in the attainment status of generating units over time in the sample. Intuitively, the generating units with unchanged attainment status would serve as controls for the generators with changed attainment status (the treated group). ${ }^{12}$ The estimated effect would be biased if there were unobserved differential trends in emissions that were correlated with the change in attainment status. This threat to identification is addressed in two ways. First, the multiple changes into and out of attainment in California diminish the potential for bias from unobserved trends. Second, the model incorporates unit-specific linear trends to control for any unit-specific trends, which would not be captured by the market-year-month fixed effects.

The estimated spillover effect could also be incorrectly identified if regulatory authorities used the additional statutory authority to attempt to reduce emissions of other pollutants. In this case, changes in attainment status would indicate variations in the prices of both $\mathrm{NO}_{\mathrm{x}}$ emissions and other pollutants, and the estimated effect would combine the direct and spillover effects. This potential confounding is limited by analyzing spillovers on $\mathrm{CO}_{2}$ emissions. During the sample period, there was still substantive disagreement over whether $\mathrm{CO}_{2}$ was a harmful pollutant and $\mathrm{CO}_{2}$ was neither listed nor regulated by the Environmental Protection Agency (EPA) as a criteria pollutant. This lack of regulatory attention to $\mathrm{CO}_{2}$ emissions suggests that the nonattainment indicator is not a proxy for an increase in the price of $\mathrm{CO}_{2}$ emissions and that the spillover effect is properly identified. ${ }^{13}$

Identification is supported further by the testable predictions from theory. In particular, Holland (2010) shows that own price effects are nonpositive

12. With change at one time in attainment status, the estimator would be similar to the wellknown difference-in-differences estimator.

13. This argument does not hold for $\mathrm{SO}_{2}$ emissions. 
for both factor demands and conditional factor demands and that output effects are nonpositive. A nonpositive estimate of $\beta$ in equation (1) with $\mathrm{NO}_{\mathrm{x}}$ emissions as the dependent variable is consistent with the theoretical predictions. With $\mathrm{CO}_{2}$ emissions as the dependent variable, there are no additional testable implications since cross price effects can be either negative or positive.

\subsection{Data}

This analysis requires data on emissions, generation, attainment status, and other regulations. Availability of the emissions data limit the sample to the years 1997 to 2004 . Emissions data come from the hourly US EPA continuous emissions monitoring systems (CEMS) for power plants. The data are very accurate, include all fossil fuel-fired generators meeting certain requirements, and have been used in a number of studies. ${ }^{14}$ The hourly generating unit-level data are aggregated to the month for three reasons. First, a number of units report emissions in hours for which they report no output. Aggregation accurately captures emissions and output while incorporating any start-up emissions from generating units. Second, if regulations caused a unit to be run fewer hours, disaggregated data would not capture this reduction with the proportional (log) estimating equations. Aggregation captures the zero production hours. Finally, the data are highly serially correlated. Aggregation reduces the problem of serial correlation.

Since California had the most variation in attainment status, the primary analysis focuses on California. Of the twelve counties in California with changes in attainment status, only three counties have relevant power plants: Contra Costa, San Francisco, and San Diego. After dropping nonreports and data inconsistencies, the model identification is based on changes in attainment status at 29 of 178 generating units. The data are discussed further in Holland (2010).

\subsection{Estimation Results}

The results from estimating equation (1) are presented in table 5.1. Each column reports the results from one of seven regressions. Column (1) reports estimates where $\ln \left(\mathrm{NO}_{\mathrm{x}}\right)$ is the dependent variable, that is, the $\mathrm{NO}_{\mathrm{x}}$ factor demand, and columns (3) and (5) capture the factor demands for $\mathrm{CO}_{2}$ and $\mathrm{SO}_{2}$. Columns (2), (4), and (6) estimate the conditional factor demands since they control for output, that is, $\ln (\mathrm{MWh})$. Column (7) reports estimates from regressing output on the same set of controls. Throughout, the unit fixed

14. For example, see Puller (2007), and Holland and Mansur (2008). 
Table 5.1

Main results: California results for $\mathrm{NO}_{x}, \mathrm{CO}_{2}$, and $\mathrm{SO}_{2}$ emissions and megawatt hours

\begin{tabular}{|c|c|c|c|c|c|c|c|}
\hline & \multicolumn{2}{|c|}{$\ln \left(\mathrm{NO}_{\mathrm{x}}\right)$} & \multicolumn{2}{|c|}{$\ln \left(\mathrm{CO}_{2}\right)$} & \multicolumn{2}{|c|}{$\ln \left(\mathrm{SO}_{2}\right)$} & \multirow{2}{*}{$\frac{\ln (\mathrm{MWh})}{(7)}$} \\
\hline & (1) & (2) & (3) & (4) & (5) & (6) & \\
\hline Nonattain & $\begin{array}{l}-0.516^{* *} \\
(0.203)\end{array}$ & $\begin{array}{c}-0.221^{*} \\
(0.131)\end{array}$ & $\begin{array}{c}-0.326^{*} \\
(0.190)\end{array}$ & $\begin{array}{c}0.003 \\
(0.030)\end{array}$ & $\begin{array}{c}-0.371^{* *} \\
(0.170)\end{array}$ & $\begin{array}{c}-0.037 \\
(0.132)\end{array}$ & $\begin{array}{c}-0.365^{*} \\
(0.200)\end{array}$ \\
\hline $\ln (\mathrm{MWh})$ & & $\begin{array}{l}0.809^{* * *} \\
(0.016)\end{array}$ & & $\begin{array}{l}0.900^{* *} \\
(0.010)\end{array}$ & & $\begin{array}{c}0.897 * * \\
(0.013)\end{array}$ & \\
\hline
\end{tabular}

Notes: There are 8,239 monthly observations for 178 generating units. $(8,188$ observations for the $\mathrm{SO}_{2}$ regressions.) Dependent variable is $\log$ of emissions or $\log$ of $\mathrm{MWh}$ of generation. Regressions additionally control for market-year-month fixed effects, generating unit fixed effects, and generating unit linear trends. Standard errors clustered at the generating unit. Controls for other regulations $\left(\mathrm{CO}, \mathrm{NO}_{2}\right.$, and eight-hour ozone nonattainment and ARP $\mathrm{NO}_{x}$ Early Election) are not jointly significant in six of the seven regressions.

**Significant at the 5 percent level.

*Significant at the 10 percent level.

effects, unit-specific linear trends, and market-year-month fixed effects are highly significant but are not reported.

The estimates of the three testable implications, in columns (1), (2), and (7), are all negative. Thus, the regression results are consistent with the theoretical predictions. Moreover these results show that approximately half of the estimated 40 percent reduction in $\mathrm{NO}_{\mathrm{x}}$ emissions can be attributed to substitution effects with the remainder being attributable to output effects.

The pollutant spillover effects are reported in columns (3) through (6). For $\mathrm{CO}_{2}$, the point estimate indicates that nonattainment designation reduced $\mathrm{CO}_{2}$ emissions by 30 percent, suggesting gross complementarity. Controlling for output, the point estimate is very near zero. This suggests that almost all of the reduction in $\mathrm{CO}_{2}$ emissions can be attributed to output effects. Similarly, the results for $\mathrm{SO}_{2}$, columns (5) and (6), also indicate gross complementarity almost entirely due to output effects. The coefficient for the output effect in column (7) estimates a 30 percent reduction in output with nonattainment designation.

The coefficients on output in (2), (4), and (6) imply emissions elasticities for the three pollutants of 0.8 to 0.9 . These estimates are statistically less than one implying that the emissions rates (emissions per MWh) are declining in output. However, the limited net effects suggest that the emissions rates do not vary substantially with changes in prices of other environmental inputs, that is, pollutant spillovers do not change emissions rates. ${ }^{15}$

Table 5.2 splits the sample into old and new plants based on the average age of the plants' units. These results show that the reductions in table 5.1

15. Holland (2010) presents additional specifications and robustness tests. 
Table 5.2

Old and new plants: California results for $\mathrm{NO}_{x}, \mathrm{CO}_{2}$, and $\mathrm{SO}_{2}$ emissions and megawatt hours

\begin{tabular}{|c|c|c|c|c|c|c|c|}
\hline & \multicolumn{2}{|c|}{$\ln \left(\mathrm{NO}_{\mathrm{X}}\right)$} & \multicolumn{2}{|c|}{$\ln \left(\mathrm{CO}_{2}\right)$} & \multicolumn{2}{|c|}{$\ln \left(\mathrm{SO}_{2}\right)$} & $\ln (\mathrm{MWh})$ \\
\hline \multicolumn{8}{|c|}{ Panel A: Old plants (average start year before 1980). 5,566 observations with 89 units. } \\
\hline Nonattain & $\begin{array}{c}-0.715^{* * *} \\
(0.230)\end{array}$ & $\begin{array}{c}-0.297^{*} \\
(0.159)\end{array}$ & $\begin{array}{l}-0.462^{* *} \\
(0.198)\end{array}$ & $\begin{array}{c}-0.011 \\
(0.020)\end{array}$ & $\begin{array}{l}-0.325^{*} \\
(0.174)\end{array}$ & $\begin{array}{c}0.124 \\
(0.140)\end{array}$ & $\begin{array}{c}-0.511^{* *} \\
(0.222)\end{array}$ \\
\hline $\ln (\mathrm{MWh})$ & & $\begin{array}{c}0.817^{* *} \\
(0.018)\end{array}$ & & $\begin{array}{l}0.883^{* *} \\
(0.012)\end{array}$ & & $\begin{array}{c}0.887^{*} \\
(0.013)\end{array}$ & \\
\hline \multicolumn{8}{|c|}{ Panel B: New plants (average start year after 1995). 2,673 observations with 89 units. } \\
\hline \multirow[t]{2}{*}{ Nonattain } & 0.154 & 0.090 & 0.044 & -0.037 & -0.536 & $-0.615^{*}$ & 0.085 \\
\hline & $(0.445)$ & $(0.279)$ & $(0.507)$ & $(0.053)$ & $(0.517)$ & $(0.364)$ & $(0.495)$ \\
\hline \multirow[t]{2}{*}{$\ln (\mathrm{MWh})$} & & $0.754^{* *}$ & & $0.957^{* *}$ & & $0.926^{*}$ & \\
\hline & & $(0.037)$ & & $(0.022)$ & & $(0.030)$ & \\
\hline
\end{tabular}

Note: Regressions additionally control for other regulations, for market-year-month fixed effects, for generating unit fixed effects, and for unit-specific linear trends.

come primarily from the reductions in output and emissions at older plants. Since newer plants are less polluting, they use the $\mathrm{NO}_{\mathrm{x}}$ input more efficiently and thus did not reduce output in response to the change in attainment status.

The results are subject to three additional caveats. First, the power of the test is reduced since electric power generators were likely not the marginal polluter targeted by the change in attainment status. In particular, the state implementation plans (SIPs) for reducing $\mathrm{NO}_{\mathrm{x}}$ emissions do not focus on electric power generation. Second, the estimates cannot control for local economic conditions that may have been correlated with changes in attainment status. Finally, the symmetry assumption requires care in interpreting the coefficients as spillovers from climate policy. Although the estimates are valid estimates of spillovers from ozone policy, they are only locally valid estimates of spillovers from climate policy.

\subsection{Conclusion}

Spillovers from climate policy are important for policy design, modeling, and benefit-cost analysis. This chapter shows that spillovers arise from output effects (which have ancillary benefits) and substitution effects (which may have ancillary benefits or ancillary costs). The ambiguous net effect highlights the importance of polluters' responses to climate policy.

The chapter then tests for ancillary benefits from climate policy in electricity power generation. The estimates are consistent with ancillary benefits from climate policy arising primarily from reductions in output (primarily at older plants) rather than from changes in emissions rates. 


\section{References}

Bell, Michelle L., Devra L. Davis, Luis A. Cifuentes, Alan J. Krupnick, Richard D. Morgenstern, and George D. Thurston. 2008. "Ancillary Human Health Benefits of Improved Air Quality Resulting from Climate Change Mitigation." Environmental Health 7 (41). doi:10.1186/1476-069X-7-41.

Burtraw, Dallas, Alan Krupnick, Karen Palmer, Anthony Paul, Michael Toman, and Cary Bloyd. 2003. "Ancillary Benefits of Reduced Air Pollution in the US from Moderate Greenhouse Gas Mitigation Policies in the Electricity Sector." Journal of Environmental Economics and Management 45:650-73.

Cifuentes, Luis, Victor H. Borja-Aburto, Nelson Gouveia, George Thurston, and Devra Lee Davis. 2001. "Assessing the Health Benefits of Urban Air Pollution Reductions Associated with Climate Change Mitigation (2000-2020): Santiago, São Paulo, México City, and New York City." Environmental Health Perspectives 109 (Supplement 3): 419-25.

Dessus, Sebastien, and David O'Connor. 2003. "Climate Policy Without Tears: CGE-Based Ancillary Benefits Estimates for Chile." Environmental and Resource Economics 25:287-317.

Dudek, Dan, Alexander Golub, and Elena Strukova. 2003. "Ancillary Benefits of Reducing Greenhouse Gas Emissions in Transitional Economies." World Development 31 (10): 1759-69.

European Environment Agency. 2004. Air Quality and Ancillary Benefits of Climate Change Policies. EEA Technical report no 4. Available at: http://www.eea.europa .eu/publications/technical_report_2006_4.

Elbakidze, Levan, and Bruce A. McCarl. 2004. "Should We Consider the CoBenefits of Agricultural GHG Offsets?" Choices Fall:25-6.

Feng, Hongli, Catherine L. Kling, and Philip W. Gassman. 2004. "Carbon Sequestration, Co-Benefits, and Conservation Programs." Choices Fall:19-24.

Greenstone, Michael. 2002. "The Impacts of Environmental Regulations on Industrial Activity: Evidence from the 1970 and 1977 Clean Air Act Amendments and the Census of Manufacturers." Journal of Political Economy 110: $1175-219$.

.2003. "Estimating Regulation-Induced Substitution: The Effect of the Clean Air Act on Water and Ground Pollution." American Economic Review Papers and Proceedings 93 (2): 442-8.

Groosman, Britt, Nicholas Z. Muller, and Erin O'Neill. 2009. "The Ancillary Benefits from Climate Policy in the United States." Middleburg College, Department of Economics. Working Paper Series no. 0920.

Holland, Stephen P. 2012. "Emissions Taxes versus Intensity Standards: SecondBest Environmental Policies with Incomplete Regulation." Journal of Environmental Economics and Management 63(3): 375-87.

. 2010. "Spillovers from Climate Policy." NBER Working Paper no. 16158. Cambridge, MA: National Bureau of Economic Research, July.

Holland, Stephen P., and Erin T. Mansur. 2008. "Is Real-Time Pricing Green? The Environmental Impacts of Electricity Demand Variance." Review of Economics and Statistics 90 (3): 550-61.

Joh, Seunghun, Yunmi Nam, Sanggyoo Shim, Joohon Sung, and Youngchul Shin. 2003. "Empirical Study on Environmental Ancillary Benefits Due to Greenhouse Gas Mitigation in Korea." International Journal of Sustainable Development 6 (3): 311-27.

Mazzi, Eric A., and Hadi Dowlatabadi. 2007. "Air Quality Impacts of Climate 
Mitigation: UK Policy and Passenger Vehicle Choice.” Environmental Science and Technology 41:387-92.

Pattanayak, Subhrendu K., Allan Sommer, Brian C. Murray, Timothy Bondelid, Bruce A. McCarl, and Dhazn Gillig. 2002. Water Quality Co-Benefits of Greenhouse Gas Reduction Incentives in U.S. Agriculture: Final Report. Available at: foragforum.rti.org/documents/Pattanayak-paper.pdf.

Plantinga, Andrew J., and JunJie Wu. 2003. "Co-Benefits from Carbon Sequestration in Forests: Evaluating Reductions in Agricultural Externalities from an Afforestation Policy in Wisconsin.” Land Economics 79 (1): 74-85.

Puller, Steven L. 2007. "Pricing and Firm Conduct in California's Deregulated Electricity Market." Review of Economics and Statistics 89 (1): 75-87.

Walsh, Michael P. 2008. "Ancillary Benefits for Climate Change Mitigation and Air Pollution Control in the World's Motor Vehicle Fleets." Annual Review of Public Health 29:1-9.

\section{Comment Charles D. Kolstad}

This chapter addresses an important question in the economics of environmental regulation - a question often given cursory lip service but rarely the subject of rigorous analysis. When an industry is subject to emission regulations for pollutant $x$, there may be changes in emissions of pollutant $y$, due either to changes in the technology of production or changes in the quantity of the underlying good produced. For instance, regulating carbon dioxide emissions can result in changes in emissions of particulate matter.

This is an important issue on many counts. A cost-benefit analysis of a proposed regulation should appropriately take into account the benefits/ costs of such spillovers. Furthermore, environmental justice issues are often important in regulatory debates and environmental justice frequently involves changes in pollutants that are not the ones being directly regulated. That is the case with carbon emissions in California. Environmental justice proponents are concerned that regulating carbon emissions will result in increases in criteria air pollutants (e.g., particulates) in low income areas of cities.

Although Professor Holland's main contribution is his empirical analysis, he does discuss the theory behind the issue of spillovers. If $\mathrm{NO}_{\mathrm{x}}$ emissions are efficiently regulated then marginal costs and benefits from $\mathrm{NO}_{\mathrm{x}}$ are always balanced, both before instituting a $\mathrm{CO}_{2}$ regulation and after. Thus nonzero spillovers from $\mathrm{CO}_{2}$ regulation in part are due to inefficient $\mathrm{NO}_{x}$ regulations.

Charles D. Kolstad is professor of economics at the University of California, Santa Barbara, a university fellow of Resources for the Future, and a research associate of the National Bureau of Economic Research.

For acknowledgments, sources of research support, and disclosure of the author's material financial relationships, if any, please see http://www.nber.org/chapters/c12149.ack. 